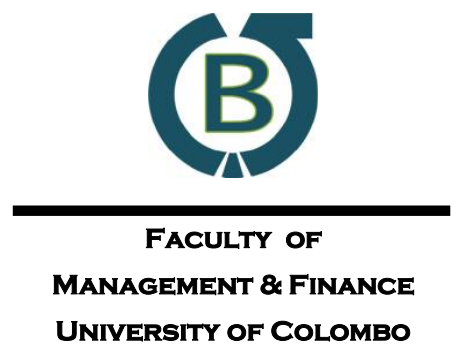

Colombo Business Journal

INTERNATIONAL JOURNAL OF

THEORY \& PRACTICE

Vol. 08, No. 01, June, 2017

\title{
Is SAFTA Desirable? Evidence from Static Theory
}

\author{
T.U.I. Peiris ${ }^{a 1}$, M. Azali ${ }^{\text {b }}$ M.S. Habibullah ${ }^{\text {b }}$, A. Hassan ${ }^{\text {b }}$ \\ ${ }^{a}$ Department of Accountancy and Finance, Sabaragamuwa University of Sri Lanka, Sri Lanka \\ ${ }^{b}$ Department of Economics, Universiti Putra Malaysia, Malaysia
}

\begin{abstract}
South Asian Free Trade Area (SAFTA) depicts a huge potentiality in expanding intra-regional trade leading to a net trade creation for the region. Yet, prevailing inter-state political disputes and inner-state conflicts within the region tend to hinder intra-regional trade. Lack of prior studies that concentrate on these political factors when assessing the desirability of South Asian trade agreements motivates the present study. Thus, this study investigates the trade creation and trade diversion effects of SAFTA after controlling for political factors. In this regard, an augmented gravity model is employed over the period 2003 to 2013. Static linear panel estimation methods of pooled ordinary least square, random effects, and fixed effect methods are used in arriving at the results. Results confirm the desirability of SAFTA with the presence of significant intra-bloc and extra-bloc trade expansions. Further, SAFTA shows a significant anticipation effect as trade expansions are significant even prior to its implementation and they continued to be significant until 2012. Also, this study empirically confirms the deleteriousness of the region's political factors in expanding trade.
\end{abstract}

Keywords: Trade Integration, SAFTA, Political Factors, South Asian Trade, Static Linear Panel Models

\section{Introduction}

This study investigates the desirability of South Asian Free Trade Area (SAFTA) with reference to the Static Theory of Trade Integration. Static Theory, which evolves from Viner's (1950) Customs Union Theory, addresses the welfare effects of Regional Trade Agreements (RTAs) considering their potential in providing trade creation and trade diversion effects for the integrated region. Trade creation leads to welfare rising as trade shifts from a high cost supplier 
member country to a low-cost supplier member country. Meanwhile, trade diversion lowers the welfare as it leads to shift trade from a low-cost supplier non-member country to a high cost supplier member country. Thus, according to Static Theory a RTA is considered desirable with the presence of net trade creation effects and undesirable with the presence of net trade diversion effects. Although this phenomenon is greatly researched worldwide, empirical concentration on South Asian RTAs is still unsatisfactory.

Among other trade agreements in the region, SAFTA depicts a huge potentiality in generating static welfare gains due to the presence of several welfare stimulant factors. Average tariff rates prior to SAFTA were very high and it is expected to bring down these higher tariffs from the initial levels of 25-30 percent to 0-5 percent by the agreement. These massive tariff reductions have the potential in expanding region's trade. In addition, some theoretically accepted trade promoting attributes may have become more effective with the implementation of SAFTA. High potential in intra-regional trade because of unexplored trade opportunities (Hassan, 2001), abundance of factors of production especially labour, similar demand structures (Kemp 1969; Linder, 1961), huge consumer base (Gehrels, 1956; Lipsey, 1957), implementation of SAFTA with gradual tariff reductions (De Melo, Panagariya, \& Rodrik, 1993; Lipsey \& Lancaster, 1956), and ever improving terms of trade (Cooper \& Massell, 1965a, 1965b) are some of these factors that enhance the potentiality of SAFTA. Yet, prevailing inter-state political disputes and inner state conflicts within the region tend to hinder intra-regional trade (Bhattacharya \& Das, 2009; Hassan, 2001; Moinuddin, 2013; Moktan, 2008). Meanwhile, trade integration literature provide evidences for the potentiality of RTAs in mitigating these deleterious political factors as countries realize the welfare benefits of regionalism (Barbieri, 2002; Martin, Mayer, \& Thoenig, 2008; Oneal \& Russett, 1997, 1999). Therefore, with the lapse of almost 10 years after implementing SAFTA, the influence of political tension on South Asian trade might have even diluted.

However, current empirical knowledge on the desirability of SAFTA is yet to reach a peak due to several issues. The limitedness of publicly available investigations and the inconsistency in available findings are considered as the major issues that hinders the empirical knowledge. The inconsistency in findings may have occurred due to different methods adopted and due to different timeframes considered. For instance, studies that used Global Trade Analysis Project (GTAP) model confirm the undesirability (Bandara \& Yu, 2003; Kumar \& Saini, 2007), while studies that used gravity model confirm the desirability of SAFTA in providing welfare gains (Bhattacharya \& Das, 2009; Moinuddin, 2013). Further, even though several studies concluded the possible influence of political factors on intra-regional trade and the static efficiency of SAFTA, such studies very rarely included these political variables in to their analytical framework. For that reason, one is still unaware about how these political factors influence region's trade and in turn their influence on static welfare gains of SAFTA. Therefore, the central 
objective of this study is to measure the static efficiency of SAFTA after controlling for political factors.

The rest of the sections of this study are structured as follows. Section 2 outlines the literature review. Section 3 explains the methodology adapted in this study. Section 4 outlines the findings and discussion. Section 5 provides the conclusion for the study.

\section{Literature Review}

Globalization became well received with the advent of new information and communication technologies. Indeed, rapid technological development, particularly in the industries of transportation and telecommunication reduced the economic barriers in exchanging goods and factors of production. Herein, the role of geographical distance emerged as irrelevant for economic transactions. Meanwhile, Regional Trade Agreements (RTA) database of World Trade Organization (WTO) indicates that almost all of its member countries have participated in at least one of RTAs so far. As such, by October 2014, the number of notified RTAs approximately increased to 585. Of these, 379 are in force. As globalization became more popular and persistent, why do countries more often tend to integrate with their neighbours over the trading partners located outside their regions? The aforementioned empirical question has been addressed with reference to RTA specific economic effects over several decades now. Static Theory of trade integration is considered as one of the main theories that intensifies these RTA specific economic benefits.

\section{Theoretical Review}

Viner (1950) introduced the static theory through the concepts of trade creation and trade diversion. Viner (1950) believes that trade creation leads to welfare rising as trade shifts from a high cost supplier member country to a low-cost supplier member country in the union. Meanwhile, trade diversion lowers the welfare as it leads to shift trade from a low-cost supplier of a non-member country to a high cost supplier member country in the union. These two concepts, trade creation and trade diversion, can be further explained with the help of following hypothetical example in Table 1.

Table 1: Price of Commodity "X": A Hypothetical Example

\begin{tabular}{cccc}
\hline & Country A & Country B & Country C \\
\hline Price of commodity X & 35 & 20 & 15
\end{tabular}


Trade creation indicates that a RTA generates trade that would not have indeed existed otherwise. Thereby, supply of the product occurs from a more efficient producer. According to the above example if country A enters into a trade agreement either with country B or country C, in both cases, country A will start importing commodity $\mathrm{X}$ from the contracting country since the domestic price of commodity X in country A (35) is higher than country B (20) or country C (15). Thus, the direction of trade will shift from a high cost member country (country A) to a low-cost member country (country B or C) generating a trade creation.

On the other hand, trade diversion indicates that a RTA diverts trade away from a more efficient supplier outside the RTA and towards a less efficient supplier within the RTA. In the above example let's further assume that country A levies a tariff of 100 per cent on commodity X. So, new prices of commodity $\mathrm{X}$ from country B is 40 and country C is 30 . Hence, country A would buy the commodity from country $\mathrm{C}$, who is the low-cost producer in this case. Later, if country A forms a Free Trade Area (FTA) with country B, then country A will buy it from country B, because due to the FTA, the price of commodity A falls to 20 in country B. This indicates that the direction of trade has shifted from an initial low cost non-member country (country C) to the high cost member country (country B) by generating a trade diversion. For more examples in this regard refer Lipsey (1960) and Hosny (2013).

As mentioned in the above theoretical review on static theory, trade creation and trade diversion are the two main static outcomes of a RTA. Further, for a RTA to be considered as desirable it should lead to a net trade creation effect. Therefore, when assessing the effectiveness of a RTA it is required to assess its static efficiency.

\section{Empirical Findings on South Asian Trade Agreements}

Static efficiency of South Asian trade agreements was investigated even before the formation of South Asian Association for Regional Corporation (SAARC). For instance, Jayaraman (1978) and Rahman, Bhuyan, and Reza (1981) investigated the potential effects of a hypothetical custom union, which comprises Bangladesh, India, Nepal, Pakistan, and Sri Lanka. However, as reported by Bandara and Yu (2003) quantitative research studies that concentrate on this phenomenon are limited due to four possible reasons. First, the regions' contribution to the global trade, investment, and growth is not momentous. Second is the data constraint in the region. Third, the published data do not provide the real picture as the "illegal trade" volume in the region is high. Finally, the existence of non-tariff barriers, which are difficult to recognize and quantify, also leads to the limitedness of such quantitative studies. Despite these possible constraints literature provides some empirical evidences. 
Govindan (1994) evaluated the trade effects of SAPTA by estimating price elasticities of food imports by the member countries. Results of the study indicate the potentiality of SAPTA in improving economic welfare and specially in securing food security in the region. DeRosa and Govindan (1995, 1996) pointed out the necessity of a further study as Govindan (1994) did not devote attention to the third country effects. Hence, DeRosa and Govindan $(1995,1996)$ extended the previous study by investigating the implications of SAPTA- Asia-Pacific Economic Cooperation (APEC) relations and included trade in manufactured goods as well. In this regard, they evaluated the unilateral tariff reductions by SAARC countries within a partial equilibrium framework. DeRosa and Govindan $(1995,1996)$ while confirming the findings of Govindan (1994), stated that SAPTA expands the intra-SAARC trade in manufactures, especially in labourintensive and other light manufactures. Moreover, they indicated that trade liberalizations with other counterparts of the world bring more welfare gains to the region when compared to intraregional liberalizations.

Hassan (2001) attempted to answer the empirical question, whether intra-SAARC trade is welfare improving or not? In addition, the impact of SAPTA and hypothetical trading blocs between Bangladesh and several other regional blocs were investigated. A basic gravity model has been employed with appropriate proxy variables for sizes of economies, levels of economic development, and transportation costs. Based on the results of the gravity model, he pointed out the desirability of further trade integration commitments, since the prevailed integration arrangements failed in creating welfare benefits. Bandara and Yu (2003) used the GTAP in order to evaluate the welfare gains of SAPTA and SAFTA. In this regard, they used the GTAP Version Five database and aggregated it into 12 regions considering Bangladesh, India, Sri Lanka and rest of the South Asia as separate regions. Further, 17 industries were considered in this regard. Bandara and Yu (2003) concluded that SAPTA and SAFTA were highly undesirable and would lead to a significant trade diversion effect. Further, they indicated that South Asia have the potentiality of gaining much more through unilateral and multilateral trade liberalizations than preferential trading arrangements.

Hirantha (2004) examined the trade creation and trade diversion effects of SAPTA with his study titled "From SAPTA to SAFTA: Gravity Analysis of South Asian Free Trade". In that study a basic gravity model has been employed by using both panel and cross sectional data analysis techniques in order to analyse the bilateral trade data during 1996 to 2002 . The results of the study contradicted with the most of the previous studies as it depicted a significant intraregional trade creation effect. Also, the trade diversion effect was found to be insignificant, as the region imports mostly from non-member countries. Further, he indicated the fact that this significant trade creation effect of SAPTA, would contribute positively towards the success of proposed SAFTA. Tumbarello (2006) investigated the trade creation and trade diversion effect of 
several preferential trading arrangements including SAPTA. A gravity equation as proposed by Soloaga and Winters (2000) has been employed by using both panel and cross sectional data analysis techniques for the period from 1984 to 2003.Tumbarello (2006) confirmed the significance of all the basic gravity variables such as, economic size, per capita income, bilateral distance, common language, and common border. Moreover, he confirmed the existence of trade creation effects and also the absences of trade diversion effects for almost all the RTAs considered. Kumar and Saini (2007) with the study titled "Economic Co-operation in South Asia: The Dilemma of SAFTA and Beyond" used the GTAP model once again to assess the potential impact of SAFTA on member countries. Further, Kumar and Saini (2007) examined the effects of alternative trade liberalization scenarios: extended trade relations with Association of Southeast Asian Nations (ASEAN), North American Free Trade Agreement (NAFTA) and European Union (EU); unilateral and multilateral trade liberalizations; and a hypothetical custom union for South Asia. They also made a conclusion quite similar to Bandara and Yu (2003), which indicates that "the welfare basis for establishing SAFTA or for deeper trade policy coordination is not very strong. Nor it is obvious that cooperation among South Asia would be forthcoming given the anticipated welfare impacts".

Rahman, Shadat, and Das (2006) examined the static welfare effects of several RTAs with special focus on SAPTA. In this regard, a gravity model has been augmented by introducing bilateral exchange rates and bilateral free trade agreements. They indicated the existence of both export creation and export diversion effects for SAPTA. In addition, they stated that Bangladesh, India, and Pakistan were likely to gain while other countries (Bhutan has not been considered in this study due to the data constraint) were negatively affected. Moktan (2008) investigated the desirability of SAPTA with the study titled "Evaluating the Intra-Regional Exports and Trade Creation and Trade Diversion Effects of Trade Agreements in SAARC Countries". An augmented gravity model, augmented by introducing policy variable and time specific fixed effects, has been employed in a pooled panel data framework for the period of 1980 to 2005 . The time period has been broken down to five sub periods as Pre-SAARC (1980-1984), Post-SAARC (1985-2005), Pre-SAPTA (1980-1994), Post-SAPTA (1995-2005), and Pre and Post (1980-2005). Results indicated a significant impact of trade agreements on exports during Post-SAARC and Post-SAPTA periods while it is insignificant in Pre-SAARC and Pre-SAPTA periods. Also, he confirmed the existence of significant trade creation effects within the region. Further, he indicated these trade creations possibly resulted from the effect of SAPTA and the "delayed impact of bilateral trade agreements" between member countries of the region.

Bhattacharya and Das (2009) examined the potential influence of SAFTA on member countries by devoting special attention to the "behind the border" and "beyond the border" constraints to bilateral trade flows during 1995 to 2008. Following the available literature, they 
defined "behind the border" constraints as "the unfavorable policy environments in the home country" while those in the partner country were defined as "beyond the border" constraints. In this regard, the error term, $\varepsilon$, of a gravity model measured through the maximum likelihood framework is has been decomposed into "single sided error term", u, which captures the effect of "behind the border" constraints and into "double sided error term", v, which denotes "beyond the border" constraints and normal error term. Four hypothetical tariff reductions ( 25 per cent, 50 per cent, 75 per cent and 100 per cent) have been evaluated in arriving at the results. Findings of the study indicated that "behind the border" constraints significantly influence exports of member countries. Further, relatively smaller member countries depicted the potentiality in achieving the maximum gain when a FTA among SAARC members becomes fully operational.

Moinuddin (2013) using a recent data set (1992-2011) investigated the determinants of trade flows and the welfare effects of SAFTA. A gravity model with standard gravity variables and additional explanatory variables to represent the openness and restrictions (exchange rate, ratio between Import and GDP, and Tariff rates) has been implemented in a panel least square regression framework. In addition, two dummy variables have been used to represent SAFTA and countries that link to "multi fibre agreements". The reported results on determinants provided several conclusions: all the standard gravity variables were significant; the impact of currency depreciation or appreciation measured by using exchange rate was not significant for all the countries; the proxy for the openness (Import-GDP Ratio) was significant; the measure of restriction indicated that the reductions in tariffs will positively affect the intra-regional trade. Further, Moinuddin (2013) confirmed the existence of trade creation effects within the region as a result of SAFTA.

The above empirical review indicates that most of the previous studies concentrated on South Asian Preferential Trade Agreement (SAPTA) and early stages of SAFTA. Further, the effect of political factors on region's trade was hardly controlled when evaluating RTAs in the region. Therefore, the empirical knowledge on the static efficiency of SAFTA is yet to reach a peak. This establishes the central gap in literature which this study aims to cover.

\section{Methodology}

Since the central objective of this study is to evaluate the static efficiency of SAFTA, trade creation and trade diversion effects are estimated. On this regard, a gravity model is employed, because in trade literature gravity model is considered as one of the most successful empirical methods with good fit (Anderson, 2011) and it depicts a high level of explanatory power (Ivus \& Strong, 2007; Bergstrand \& Egger, 2011) also "have produced some of the clearest and most robust empirical findings” (Leamer \& Levinsohn, 1995). 
Tinbergen (1962) introduced standard gravity equation, which models the trade between two countries as a function of economic sizes and distance between them. Equation 1 depicts the most basic form of a gravity model.

$\ln \left(T_{i j}\right)=\alpha+\beta_{1} \ln \left(G D P_{i}\right)+\beta_{2} \ln \left(G D P_{j}\right)+\beta_{3} \ln \left(D I S_{i j}\right)+\varepsilon_{i j}$

where, $\ln \left(G D P_{i}\right)$ and $\ln \left(G D P_{j}\right)$ denote natural logarithms of gross domestic production (GDP) values in country ${ }_{i}$ and country ${ }_{j}$. According to Tinbergen (1962) these economic sizes are included to represent demand and supply forces of importing and exporting countries respectively. $\ln \left(D I S_{i j}\right)$ indicates natural logarithms of physical distance between economic centers of country $\mathrm{i}$ and $\mathrm{j}$. The distance variable is included in order to capture the trade frictions or trade costs such as transport cost. $\varepsilon_{i j}$ is the error term.

\section{Augmenting the Basic Gravity Model}

As gravity models provide normal levels of bilateral trade, dummy variables can be used to evaluate deviation of trade from normal levels as a result of an RTA (Martinez-Zarsozo, Felicitas, $\&$ Horsewood, 2009). Therefore, in order to estimate trade creation and trade diversion effects two dummy variables are introduced accordingly. Following Magee (2008), Martinez-Zarsozo at el. (2009), and Moinuddin (2013) several other commonly used set of dyad variables are introduced to the standard gravity model. Country pair per capita GDP values are used to represent income levels of respective countries. Other dyad variables may represent whether countries are land locked, speak the same language, and colonial ties. Moreover, international trade in South Asia is discouraged due to prevailing political factors that disturb their intercountry relationships. Therefore, political factors are also used to augment the Equation 1 above.

The decision to form a RTA is not exogenous or in other words trade policy is not an exogenous variable. According to Baier and Bergstrand (2007) this endogeneity shown in RTA dummy variables can be eliminated by using panel data models with country specific fixed effects. Further, other country specific factors, which are not controlled by the present model specifications, may lead to bias inferences. A common way to overcome this issue is to include exporter fixed effects and importer fixed effects (Magee, 2008; Martinez-Zarsozo at el., 2009). Thus, a typical gravity model specification that estimates the effects of SAFTA would be;

$$
\begin{aligned}
& \ln T_{i j t}=\beta_{0}+\alpha_{t}+\alpha_{i}+\alpha_{j}+\beta_{1} \ln \left(G D P_{i t} \cdot G D P_{j t}\right)+\beta_{2} \ln \left(P G D P_{i t} \cdot P G D P_{j t}\right)+\beta_{3} \ln (D I S)_{i j} \\
& +\gamma_{t}\left(T C_{i t}\right)+\delta_{t}\left(T D_{i t}\right)+\sum_{l=1}^{3} \chi_{l}\left(X_{i j}\right)+\varphi_{1} P P F_{i t}+\theta_{1} P P F_{j t}+v_{i j t}
\end{aligned}
$$


where, PGDP ${ }_{i t}$ and PGDP $_{\mathrm{jt}}$ denotes the per capita GDPs of country $\mathrm{i}$ and country $\mathrm{j}$. Following substantial amount of literature, the interaction terms of country pair GDP (GDP $\left.\mathrm{it}_{\mathrm{it}} \mathrm{GDP}_{\mathrm{jt}}\right)$ and PGDP $\left(\right.$ PGDP $_{\mathrm{it} .}$ PGDP $_{\mathrm{jt}}$ ) are used instead of regressing them independently. $X_{i j}$ represents a vector of dummy variables that represent common language $(l=1)$, colonial ties $(l=2)$, and land lockedness $(1=3)$. Governance indicators estimated by Kaufmann, Kraay, and Zoido-Labaton (1999) are used as proxies for political factors. They are: Control of Corruption, Government Effectiveness, Political Stability and Absence of Violence/Terrorism, Regulatory Quality, Voice and Accountability, and Rule of Law. According to Globerman and Shapiro (1999) these indicators are considered superior to other indices that have been used elsewhere, because they are estimated using 31 different qualitative indicators from 13 different reliable sources. Thus, these meta-indices would encompass most of the other measures. However, these indices highly correlate with each other. Therefore, following Globerman and Shapiro (1999), an aggregate measure is obtained by estimating their first principal component for both country $\mathrm{i}$ and country $\mathrm{j}$. These principal components of governance indicators in country $i\left(\mathrm{PPF}_{\mathrm{i}}\right)$ and country $\mathrm{j}\left(\mathrm{PPF}_{\mathrm{j}}\right)$ are used to represent political factors.

$\mathrm{TC}_{\mathrm{ijt}}$ represent dummies for trade creation effect and $\mathrm{TD}_{\mathrm{ijt}}$ are dummies for trade diversion effect of SAFTA. $\mathrm{TC}_{\mathrm{ijt}}=1$ when both country $\mathrm{i}$ and $\mathrm{j}$ are SAFTA members and 0 , otherwise. $\mathrm{TD}_{\mathrm{ijt}}=1$ when only one country is a SAFTA member and 0, otherwise. $\alpha_{t}$ is supposed to represent omitted variables that capture any common shocks that affect trade in a particular year and the time trends in trade. $\alpha_{i}$ denotes importer country specific fixed effects. Exporter country specific fixed effects are denoted by $\alpha_{j} . v_{i j}$ is the error term. The other variables are same as in Equation1.

\section{Predicting Trade Expansions}

When examining the desirability of SAFTA it is equally important to examine trade expansions that SAFTA brings to each member country. In this regard, actual levels of trade are compared with predicted levels. Since the dependent variable (trade) in Equation 2 above is given as a log value, consistent predictions are generated following Wooldridge (2006). On this regard, Wooldridge (2006) introduces the following equation.

$\hat{T}_{1}=\exp \left(\frac{\sigma^{2}}{2}\right) \times \exp (\ln T)$

where, $(\ln T)$ is the fitted or expected value of a regression for $\ln T$. 
Expected values for the trade in the absence of SAFTA can be taken by adjusting $\mathrm{TC}_{\mathrm{ijt}}=0$ and $\mathrm{TD}_{\mathrm{ijt}}=0$ in the Equation 2 above. Then, applying these expected values to Wooldridge's (2006) equation, trade predictions $\left(\hat{T}_{i j t}\right)$ for member countries are obtained. The difference between actual trade $\left(\mathrm{T}_{\mathrm{ijt}}\right)$ and $\hat{T_{i j t}}$ would provide trade expansions due to SAFTA. Thus, the summation of these differences over the member countries would account for the intra-bloc effect while the summation for other countries would account for extra-bloc change. That is;

$$
\text { IntraBlock }- \text { Effect } t_{i j t}=\sum_{i j \in S A F T A}\left(T_{i j t}-\hat{T}_{i j t}\right)
$$

and,

$$
\text { ExtraBlock-Effect } i_{i j t}=\sum_{i j \notin S A F T A}\left(T_{i j t}-\hat{T}_{i j t}\right)
$$

However, these intra-bloc changes and extra-bloc changes do not comply with the Viner's (1950) definitions of trade creation and trade diversion. The results of the Equation 4 above are the total trade expansion $\left(\mathrm{TE}_{\mathrm{ij}}\right)$ within the region as a result of SAFTA. Thus, $\mathrm{TE}_{\mathrm{ijt}}$ includes the trade diversion effect as well. Since $\mathrm{TE}_{\mathrm{ijt}}$ should be non-negative, it can be represented by;

For simplicity in terminology let us assume, ${ }_{i j t}^{\text {safta }}$ as intra-regional actual trade and ${ }^{\hat{T_{i j t}}} \stackrel{\hat{\text { safa }}}{\text { as }}$ predicted intra-regional trade with the absence of SAFTA. And thus,

$$
T E_{i j t}=\left\{\begin{array}{ccc}
T_{i j t}^{\text {safta }}-T_{i j t}^{\hat{\text { safta }}} & \text { if } & T_{i j t}^{\text {saffa }} \geq T_{i j t}^{\hat{\text { safta }}} \\
0 & \text { if } & T_{i j t}^{\text {saffa }}<T_{i j t}^{\hat{\text { safta }}}
\end{array}\right.
$$

According to the formal definition of trade diversion, an increase in $\mathrm{TE}_{\mathrm{ijt}}$ should accompanied by a fall in extra-regional trade. Hence, it can be shown as;

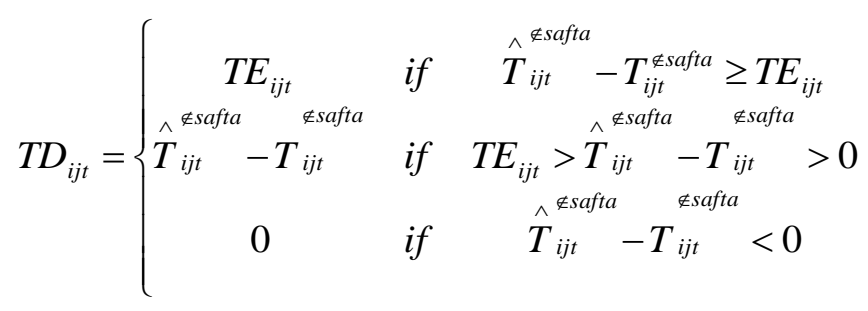


where, $\hat{T}_{i j t}^{\notin s a f t a}$ indicates the total extra-bloc trade in the absence of SAFTA. $T_{i j t}^{\notin s a f t a}$ indicates the total extra-bloc actual trade. TD indicates trade diversion. And thus, trade creation (TC) would be equal to the difference between Equation 6 and 7, which is expected to be positive. It can be shown as follows;

$T C_{i j t}=T E_{i j t}-T D_{i j t}$

Equation 2 is estimated in obtaining the trade creation and trade diversion effects of SAFTA. In this regard, static linear panel estimation methods of pooled ordinary least square (pooled OLS), random effects, and fixed effect methods are employed. The data set covers 87 commonly traded partner countries, which includes only seven (07) South Asian countries. Bhutan is not considered with this study due to lack of data. Sample size is limited to 87 countries considering the commonness of trading partners and availability of data. Therefore, a maximum of 82,302 (87 $\times 86 \times 11$ ) observations are used in estimating the panel models. Appendix 1 provides the list of countries used in this study. The estimation of gravity equations is repeated for the three proxies used to represent trade that is natural logarithms of imports, exports and total trade (imports plus exports). Appendix 2 provides a detailed explanation on the data used to represent each of the gravity variables.

\section{Empirical Findings and Discussion}

Results for the augmented gravity model, separately for imports, exports, and total trade models, are reported in Table 2. These results are presented over five (05) modelling techniques, which are used depending on various fixed effects incorporated in to the model. Model 1 to model 3 (M1, M2, and M3) reports the coefficients for traditional panel data analysis techniques of pooled Ordinary Least Squares (OLS), random effects, and fixed effects respectively. Several specification tests are then applied to select the suitable modelling technique. First, BreuschPagan LM test is employed to see the suitability of panel models over pooled OLS. Since it rejects the null hypothesis that variances across countries are zero for all the import, export, and total trade models, random effect model is preferred over pooled OLS. Hausman test is then used to select in between random effects and fixed effects models. As Hausman test rejects the null hypothesis of cross-sectional specific effects is not correlated with independent variables, fixed effects model is considered for further analysis. In addition, as the test for time fixed effects rejects the null hypothesis that coefficients for all years are jointly equal to zero, time fixed effects are introduced accordingly. Thus, Model 4 (M4) represents results after controlling for time fixed effects. Further, time varying importer and exporter fixed effects are introduced under model 5 (M5). However, when moving from M4 to M5 a dramatic reduction in goodness of fit is 
observed. Due to this significant loss in goodness of fit in M5, fixed effect panel model with time fixed effects (M4) is considered when interpreting the results.

Table 2: Gravity Model Estimates for Imports, Exports, and Total Trade

\begin{tabular}{|c|c|c|c|c|c|c|}
\hline \multirow{2}{*}{\multicolumn{2}{|c|}{ Gravity Variables }} & \multicolumn{5}{|c|}{ Traditional Panel Models } \\
\hline & & $\mathbf{M 1}^{\mathrm{a}}$ & M2 & M3 & $\mathbf{M 4}^{\mathrm{a}}$ & M5 $^{\mathbf{a}}$ \\
\hline & $1.3734^{*}$ & $1.2386^{*}$ & $1.2297^{*}$ & $1.1778^{*}$ & \\
\hline \multicolumn{2}{|c|}{$\begin{array}{r}\text { lnGDPij-imports } \\
\text {-exports }\end{array}$} & $0.1383^{*}$ & $1.3027^{*}$ & $1.1110^{*}$ & $1.1005^{*}$ & \\
\hline \multicolumn{2}{|c|}{-tot.trade } & $1.0723 *$ & $1.1100^{*}$ & $0.8297 *$ & $0.8047^{*}$ & \\
\hline \multicolumn{2}{|c|}{ lnPGDPij-imports } & $-0.0336^{*}$ & $-0.5255^{*}$ & $-0.6511 *$ & $-0.5997 *$ & \\
\hline \multicolumn{2}{|c|}{-exports } & $0.1152 *$ & $-0.5136^{*}$ & $-0.4356^{*}$ & $-0.3998^{*}$ & \\
\hline \multicolumn{2}{|c|}{-tot.trade } & $-0.0172 * * *$ & $-0.3821^{*}$ & $-0.1769 *$ & $-0.1575^{* *}$ & \\
\hline \multirow[t]{3}{*}{$\operatorname{lnDistij}$} & -imports & $-1.5925^{*}$ & $-1.7423^{*}$ & & & \\
\hline & -exports & $-1.4777 *$ & $-1.8668^{*}$ & & & \\
\hline & -tot.trade & $-1.3180 *$ & $-1.6116^{*}$ & & & \\
\hline \multirow[t]{3}{*}{ TCim } & -imports & $1.9865 *$ & $0.9274 *$ & $1.0832 *$ & $1.1390 *$ & $1.4456^{*}$ \\
\hline & -exports & $2.7377^{*}$ & $0.8464^{*}$ & $0.9153^{*}$ & $0.9518^{*}$ & $1.4488^{*}$ \\
\hline & -tot.trade & $1.3632 *$ & $1.0751^{*}$ & $1.2654^{*}$ & $1.2993^{*}$ & $0.8181 *$ \\
\hline \multirow[t]{3}{*}{ TDim } & -imports & $1.3146^{*}$ & $2.1219^{*}$ & $2.3574 *$ & $2.4523^{*}$ & 0.9814* \\
\hline & -exports & $1.3788 *$ & $1.7223^{*}$ & $1.8798 *$ & $1.9257 *$ & $0.8602 *$ \\
\hline & -tot.trade & $0.6691 *$ & $1.6047 *$ & $1.8188^{*}$ & $1.8895^{*}$ & $0.6473 *$ \\
\hline \multirow[t]{3}{*}{ Lang } & -imports & $1.1829 *$ & $1.2862 *$ & & & \\
\hline & -exports & $0.7497^{*}$ & $1.2934^{*}$ & & & \\
\hline & -tot.trade & $0.7024 *$ & $0.9817 *$ & & & \\
\hline \multirow[t]{3}{*}{ Col } & -imports & $0.1306^{*}$ & $-0.3531^{*}$ & & & \\
\hline & -exports & $0.5635^{*}$ & -0.1525 & & & \\
\hline & -tot.trade & $0.5050^{*}$ & -0.1329 & & & \\
\hline \multicolumn{2}{|c|}{ Lanlock-imports } & $-1.0341^{*}$ & $-1.4533^{*}$ & & & \\
\hline & -exports & $0.5524 *$ & $-1.4548 *$ & & & \\
\hline & -tot.trade & $-0.3548 *$ & $-1.2872 *$ & & & \\
\hline \multirow[t]{3}{*}{ PPFi } & -imports & $-0.1344 *$ & $-0.4250^{*}$ & $-0.3977 *$ & $-0.3809^{*}$ & \\
\hline & -exports & $0.2198 *$ & $-0.4679 *$ & $-0.0518 * * *$ & -0.0396 & \\
\hline & -tot.trade & $-0.0873 *$ & $-0.3364 *$ & $-0.1689^{*}$ & $-0.1586^{*}$ & \\
\hline \multirow[t]{3}{*}{ PPFj } & -imports & $-0.2374 *$ & $-0.4462 *$ & $-0.1275^{*}$ & $-0.1109 *$ & \\
\hline & -exports & $0.2195 *$ & $-0.3559 *$ & $-0.3042 *$ & $-0.2919^{*}$ & \\
\hline & -tot.trade & $1.2500 *$ & $-0.3159 *$ & $-0.1995^{*}$ & $-0.1891^{*}$ & \\
\hline
\end{tabular}

Contd. 


\begin{tabular}{|c|c|c|c|c|c|c|}
\hline \multirow{2}{*}{\multicolumn{2}{|c|}{ Gravity Variables }} & \multicolumn{5}{|c|}{ Traditional Panel Models } \\
\hline & & \multirow{2}{*}{$\frac{\mathbf{M 1}^{\mathbf{a}}}{-39.6508^{*}}$} & \multirow{2}{*}{$\frac{\text { M2 }}{-22.4736^{*}}$} & \multirow{2}{*}{$\frac{\text { M3 }}{-35.0902 *}$} & \multirow{2}{*}{$\frac{\mathbf{M 4}^{\mathbf{a}}}{-33.3311^{*}}$} & \multirow{2}{*}{$\frac{\text { M5 }^{\mathrm{a}}}{5.4184^{*}}$} \\
\hline Cons & -imports & & & & & \\
\hline & -exports & $4.1963 *$ & $-25.1161 *$ & $-33.1610 *$ & $-33.2524^{*}$ & $5.7562 *$ \\
\hline & -tot.trade & $-38.2940 *$ & $-18.3538^{*}$ & $-21.9941 *$ & $-21.0474 *$ & $8.4663 *$ \\
\hline \multirow[t]{3}{*}{$\mathrm{R} 2$} & -imports & 0.7878 & 0.5673 & 0.4228 & 0.4223 & 0.1850 \\
\hline & -exports & 0.9170 & 0.5815 & 0.4448 & 0.4479 & 0.1670 \\
\hline & -tot.trade & 0.8556 & 0.5961 & 0.5066 & 0.5045 & 0.0129 \\
\hline \multicolumn{2}{|c|}{ \# observations } & 82302 & 82302 & 82302 & 82302 & 82302 \\
\hline \multicolumn{2}{|c|}{ Time Fixed Effects } & yes & No & No & Yes & yes \\
\hline \multicolumn{2}{|c|}{ Importer Fixed Effects } & yes & No & No & No & yes \\
\hline \multicolumn{2}{|c|}{ Exporter Fixed Effects } & yes & No & No & No & yes \\
\hline \multicolumn{2}{|c|}{ LM Test $^{\mathrm{P}}$} & -imports 0.0000 & -exports 0.0000 & \multicolumn{2}{|c|}{ - tot.trade 0.0000} & \\
\hline \multicolumn{2}{|c|}{ Hausman test } & -imports $1032 *$ & -exports $909^{*}$ & \multicolumn{2}{|c|}{ - tot.trade $1020^{*}$} & \\
\hline \multicolumn{2}{|c|}{ Testparm } & -imports $16.04 *$ & -exports $6.10^{*}$ & - tot.tr & $11.30 *$ & \\
\hline
\end{tabular}

Note: *,**, \& *** Indicates $P$-Values less than $0.01,0.05$, and 0.1 respectively. a - Time and country specific dummies are not reported. ${ }^{p}$ - Indicates $P$-Values for several post estimation tests. Post estimation tests are estimated before obtaining robust standard errors. Importer and exporter fixed effects in M5 are time varying.

According to the reported results in Table 2, trade creation effects of SAFTA measured through $\mathrm{TC}_{\mathrm{ij}}$ dummies are statistically significant for all the models. All the models depict relatively higher trade creation effects. This indicates that intra-regional imports increase by 212 per cent $\left(\mathrm{e}^{1.1390}-1=212\right)$, intra-regional exports by 159 per cent $\left(\mathrm{e}^{0.9518}-1=159\right)$, and intraregional trade in general by 267 per cent $\left(\mathrm{e}^{1.2993}-1=267\right)$ as a result of SAFTA. Several previous studies also presented similar trade creation magnitudes for trade agreements in the region. For instance, Hirantha (2004) report a 377 per cent of trade creation effect for SAPTA; Moktan (2008) show a 141 per cent improvement in exports in the post SAPTA periods; Akhter and Ghani (2010) indicate that a hypothetical block among Pakistan, India, and Sri Lanka would improve trade by 30 times following SAFTA. TD im dummy variables, which are used to measure the trade diversion effects, depict positively significant coefficients. This indicates that SAFTA would not lead to a decrease in trade with non-member countries; instead it expands extra-bloc trade as well. Extra-bloc imports increase by 1061 per cent $\left(\mathrm{e}^{2.4523}-1061\right)$, exports by 586 per cent $\left(\mathrm{e}^{1.9257}-1=586\right)$, and trade in general by 662 per cent $\left(\mathrm{e}^{1.8895}-1=662\right)$. Hirantha $(2004)$, and Akhter and Ghani (2010) also indicated the existence of extra-bloc trade expansions following other previous South Asian intra-regional trade agreements as well. The PPF variable, which is used to control for political factors, is found statistically significant for almost all the models. 
Figure 1 shows the predicted trade creation effects for Bangladesh, India, Pakistan, and Sri Lanka. Afghanistan, Maldives and Nepal are not included to the figure as their trade creation values are relatively lower.

\section{Figure 1: Trade Creation Effect of SAFTA (\$ Millions)}

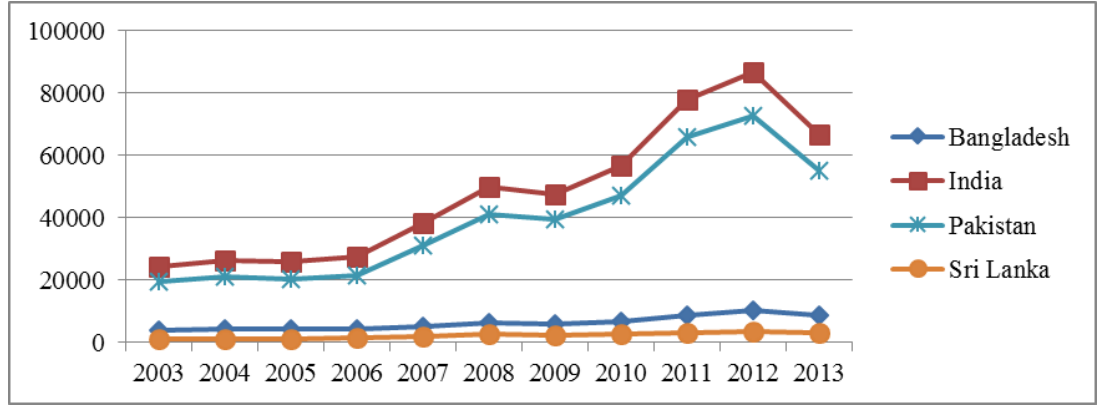

Note: Trade creation forecasts during 2003 to 2013

Trade creation effects are observed even prior to the implementation of SAFTA (2003 to 2006). This may have resulted due to the anticipation effect of firms. Because it would lead to affect trade flows even before the implementation of trade agreements (Frankel, 1997). Magee (2008) also reports insignificant but positive anticipation effects for FTAs. From 2006 to 2008, which is soon after the implementation of SAFTA, both India and Pakistan depict substantial improvement in their trade creation process. However, very next year it drops slightly for all the countries. This slight drop in trade creation might have resulted due to the global economic meltdown process which took place during that period. From 2009 onwards it increases steadily for all the countries till 2012, which records the peak year for trade creation effects of SAFTA. Then it depicts a huge drop for all the countries. This indicates that intra-bloc trade expansion effects of SAFTA are significant over the period 2006 to 2012. Thus, results show a close affiliation to the previous empirical findings as Magee (2008) reports year six as the peak year for FTAs in providing trade effects for the integrated region.

\section{Conclusion}

Recognizing the requirement of an in-depth analysis of South Asian trade integration, the present study measures static welfare effects of SAFTA. In addition, following the conclusions made by previous studies regarding trade deleteriousness of region's political factors, this study extends the analysis to have an empirically tested result for political factors as well. Results confirmed the presence of significant intra-bloc and extra-bloc trade expansions following SAFTA. That is, intra-regional imports increased by 212 per cent, intra-regional exports by 159 per cent, and total trade by 267 per cent. Interestingly, a trade diversion is not observed following 
SAFTA. Instead, quite significant extra-bloc trade expansions are observed for all the import, export, and total trade models. The aggregate effect of political factors showed statistically significant coefficients. Therefore, it empirically confirms the existence of significant governance and institutional factors within South Asian political environment that might hinder region's international trade. Trade creation predictions for individual countries reveal that relatively developed countries in the region attract highest benefit while lesser developed countries gain marginally out of this trade agreement.

\section{References}

Akhter, N., \& Ghani, E. (2010). Regional integration in South Asia: An analysis of trade flows using the Gravity Model. The Pakistan Development Review, 49(2), 105-118.

Anderson, J.E. (2011). The Gravity Model. Retreived from: http://www.nottingham.ac.uk/ gep/documents/lectures/nottm-lectures-in-int-economics/2011/ jandersonbackgroundreading.pdf.

Baier, S. L., \& Bergstrand, J. H. (2007). Do free trade agreements actually increase members' international trade? Journal of International Economics, 71, 72-95.

Bandara, S. J., \& Yu, W. (2003). How desirable is the South Asian Free Trade Area? A quantitative economic assessment. The World Economy, 26, 1293-1323.

Barbieri, K. (2002). The liberal illusion: Does trade promote peace? Ann Arbor: University of Michigan Press.

Bergrstrand, J. H, \& Egger, P. (2011). Gravity equations and economic frictions in the world economy. In D. Bernhofen, R. Falvey, D. Green-away, \& U. Krieckemeier, (Eds.), Palgrave handbook of international trade. New York: Palgrave-Macmillan Press, in press.

Bhattacharya, S. K., \& Das, G. G. (2009). Do South-South trade agreements enhance member countries' trade? Evaluating implications for development potential in the context of SAARC (UNU-CRIS Working Papers, W-20011/2).

Cooper, C. A., \& Massell, B. F. (1965a). Toward a general theory of customs union for developing countries. The Journal of Political Economy, 73(5), 461-476.

Cooper, C. A., \& Massell, B. F. (1965b). A new look at customs union theory. The Economic Journal, 75(300), 742-747.

De Melo, J., Panagariya, A., \& Rodrik, D. (1993). The new regionalism: A country perspective. In J. De Melo \& A. Panagariya (Eds.), New dimensions in regional integration. Cambridge University Press.

DeRosa, D. A., \& Govindan, K. (1996). Agriculture, trade, and regionalism in South Asia. Journal of Asian Economics, 7(2), 293-316. 
DeRosa, D. A., \& Govindan, K. (1995). Agriculture, trade, and regionalism in South Asia (Food, Agriculture, and the Environment Discussion Paper No. 7). Washington DC: International Food Policy Research Institute.

Frankel, J. A. (1997). Regional trading blocs in the world economic system. Washington, DC: Institute for International Economics. Mimeo.

Gehrels, F. (1956). Customs union from a single-country viewpoint. The Review of Economic Studies, 24(1), 61-64.

Globerman, S., \& Shapiro, D. M. (1999). The impact of government policies on foreign direct investment: The Canadian experience. Journal of International Business Studies, 30(3), 513532.

Govindan, K. (1994). A South Asian Preferential Trading Arrangement: Implications for agricultural trade and economic welfare (Research report for Robert McNamara Fellowship). Washington, DC: World Bank.

Hassan, M. K. (2001). Is SAARC a viable economic bloc? Evidence from Gravity Model. Journal of Asian Economics, 12, 263-290.

Hirantha, S. W. (2004). From SAPTA to SAFTA: Gravity analysis of South Asian free trade. Paper presented at the European Trade Study Group (ETSG) Programme, Nottingham.

Hosny, A. S. (2013). Theories of economic integration: A survey of the economic and political literature. International Journal of Economy, Management and Social Sciences, 2(5), 133155.

Ivus, O., \& Strong, A. (2007). Modeling approaches to the analysis of trade policy: Computable general equilibrium and gravity models. In W. A. Kerr \& J. D. Gaisford (Eds.), Handbook on international trade policy. Cheltenham, UK: Edward Elgar.

Jayaraman, T. K. (1978). Economic cooperation in the Indian Sub-continent - A customs union approach. New Delhi: Orient Longman.

Kaufmann, D., Kraay, A., \& Zoido-Lobaton, P. (1999). Aggregating governance indicators (World Bank Working Paper No. 2195). World Bank.

Kemp, M. (1969). A contribution to the general equilibrium theory of preferential trading. Amsterdam: North-Holland Publishing Co.

Kumar, A. G., \& Saini, G. K. (2007). Economic co-operation in South Asia: The dilemma of SAFTA and beyond (Working Paper No. 017). Mumbai: Indira Ghandhi Institute of Development Research.

Leamer, E. E., \& Levinsohn, J. (1995). International trade theory: The evidence. In G. M. Grossman \& K. Rogo (Eds.), Handbook of international economics, Volume 3. Amsterdam: Elsevier Science.

Linder, S. B. (1961). An essay on trade and transformation. New York: John Wiley \& Sons.

Lipsey, R. G. (1957). The theory of customs unions: Trade diversion and welfare. Economica, 24, 40-46. 
Lipsey, R. G. (1960). The theory of customs unions: A general survey. The Economic Journal, 70(279), 496-513.

Lipsey, R. G., \& Lancaster, K. (1956). The general theory of second best. The Review of Economic Studies, 24(1), 11-32.

Magee, C. S. P. (2008). New measures of trade creation and trade diversion. Journal of International Economics, 75, 349-362.

Martin, P., Mayer, T., \& Thoenig, M. (2008). Make trade not war? Review of Economic Studies, 75, 865-900.

Martinez-Zarsozo, I., Felicitas, D., \& Horsewood, N. (2009). Are regional trade agreements beneficial? Static and Dynamic Panel Gravity Models. North American Journal of Economics and Finance, 20, 46-65.

Moinuddin, M. (2013). Fulfilling the promises of South Asian integration: A gravity estimation (ADBI Working Paper Series No. 415). Asian Development Bank.

Moktan, S. (2008). Evaluating the intra-regional exports and trade creation and trade diversion effects of trade agreements in SAARC countries. South Asia Economic Journal. 9(2), 233260.

Oneal, J. R., \& Russett, B. M. (1997). The classical liberals were right: Democracy, interdependence, and conflict, 1950-1985. International Studies Quarterly, 41(2), 267-294.

Oneal, J. R., \& Russett, B. M. (1999). Assessing the liberal peace with alternative specifications: Trade still reduce conflicts. Journal of Peace Research, 36(4), 423-442.

Rahman, M. K., Bhuyan, A. R., \& Reza, S. (1981). The trade effects of a South Asian customs union: An expository study. The Pakistan Development Review, 20(1), 61-80.

Rahman, M., Shadat, W. B., \& Das, N. C. (2006). Trade potential in SAFTA: An application of Augmented Gravity Model (CPD Occasional Paper Series 61). Dhaka: Centre for Policy Dialogue (CPD).

Soloaga, I., \& Winters, L. A. (2000). Regionalism in the nineties: What effect on trade? The North American Journal of Economics and Finance, 12(1), 1-29.

Tinbergen, J. (1962). Shaping the world economy. New York, Twentieth Century Fund.

Tumbarello, P. (2006). Are regional trade agreements in Asia stumbling or building blocs? Some implications for the Mekong countries. Paper prepared for the seminar on Accelerating Development in the Mekong Region-the Role of Economic Integration, Siem Reap, Cambodia, June, 26-27.

Viner, J. (1950). The customs union issue. New York: Carnegie Endowment for International Peace.

Wooldridge, J. (2006). Introductory econometrics: A modern approach. Mason, OH: Thomson South-western. 
Appendix 1: Country List

\begin{tabular}{llllll}
\hline Afghanistan & Chile & Greece & Maldives & Poland & Tanzania \\
Algeria & Hong Kong & Hungary & Malta & Portugal & Thailand \\
Argentina & China & Iceland & Mauritius & Qatar & Trinidad and Tobago \\
Australia & Colombia & India & Mexico & Romania & Tunisia \\
Austria & Costa Rica & Indonesia & Morocco & Russian Federation & Turkey \\
Azerbaijan & Cote d'Ivoire & Ireland & Myanmar & Saudi Arabia & Ukraine \\
Bahrain & Croatia & Jamaica & Nepal & Senegal & United Arab Emirates \\
Bangladesh & Cyprus & Japan & Netherlands & Singapore & United Kingdom \\
Barbados & Czech Republic & Jordan & New Zealand & Slovak Republic & United States \\
Belarus & Denmark & Korea & Norway & Slovenia & Uruguay \\
Belgium & Estonia & Kuwait & Oman & South Africa & Zambia \\
Brazil & Fiji & Lebanon & Pakistan & Spain & Zimbabwe \\
Bulgaria & Finland & Luxembourg & Paraguay & Sri Lanka & \\
Cameroon & France & Macedonia & Peru & Sweden & \\
Canada & Germany & Malaysia & Philippines & Switzerland & \\
\hline
\end{tabular}

\section{Appendix 2: Data Sources and Descriptions}

Bilateral trade: Reference Source: Among others, Soloaga and Winters (2000) and Martinez-Zarzoso and Suarez-Burguet (2005). Data Source: IMF DOTS database and World Bank Database. Description: imports, exports, and total trade (imports plus exports) between country $y_{i}$ and country $y_{j}$ at time $t$ measured in US\$ millions ${ }^{1}$.

Size of the economy: Reference Source: Among others, Hirantha (2004), and Sharma \& Chua (2000). Data Source: World Bank Database. Description: approximated by GDP at current price in US\$.

Level of Development: Reference Source: Among others, Hirantha (2004), and Sharma \& Chua (2000). Data Source: World Bank Database. Description: approximated by per capita GDP at current price in US\$.

Control of Corruption: Data Source: World Bank Database of Worldwide governance indicators. Description: This indicator "captures perceptions of the extent to which public power is exercised for private gain, including both petty and grand forms of corruption, as well as "capture" of the state by elites and private interests" (Kaufmann et al.,1999a).

\footnotetext{
${ }^{1}$ The selection among imports, exports, and total trade for a gravity model specification has been widely debated in the literature. Kandogan (2004) provides a detailed view on this regard.
} 
Government Effectiveness: Data Source: World Bank Database of Worldwide governance indicators. Description: This indicator "captures perceptions of the quality of public services, the quality of the civil service and the degree of its independence from political pressures, the quality of policy formulation and implementation, and the credibility of the government's commitment to such policies" (Kaufmann et al.,1999a).

Political Stability and Absence of Violence/Terrorism: Data Source: World Bank Database of Worldwide governance indicators. Description: this indicator "captures perceptions of the likelihood that the government will be destabilized or overthrown by unconstitutional or violent means, including politically-motivated violence and terrorism" (Kaufmann et al.,1999a).

Regulatory Quality: Data Source: World Bank Database of Worldwide governance indicators. Description: this indicator "captures perceptions of the ability of the government to formulate and implement sound policies and regulations that permit and promote private sector development" (Kaufmann et al.,1999a).

Voice and Accountability: Data Source: World Bank Database of Worldwide governance indicators. Description: this indicator "captures perceptions of the extent to which a country's citizens are able to participate in selecting their government, as well as freedom of expression, freedom of association, and a free media" (Kaufmann et al.,1999a).

Rule of Law: Data Source: World Bank Database of Worldwide governance indicators. Description: this indicator "captures perceptions of the extent to which agents have confidence in and abide by the rules of society, and in particular the quality of contract enforcement, property rights, the police, and the courts, as well as the likelihood of crime and violence" (Kaufmann et al.,1999a). 